удК 331.108

\title{
ОРГАНІЗАЦІЙНА КУЛЬТУРА ЯК СОЦІАЛЬНА ПІДСИСТЕМА КУЛЬТУРИ ПІДПРИЕМСТВА
}

\section{ORGANIZATIONAL CULTURE AS A SOCIAL SUBSYSTEM OF THE ENTERPRISE'S CULTURE}

\author{
Семененко Олена Володимирівна \\ кандидат економічних наук, доцент, викладач, \\ Відкритий міжнародний університет розвитку людини «Україна» \\ ORCID: https://orcid.org/ 0000-0002-7880-1890 \\ Semenenko Olena \\ Open International University of Human Development «Ukraine»
}

\begin{abstract}
У статті висвітлюється одна з проблем культури підприємства - ії соціальна підсистема, організаційна культура. На основі теоретичного дослідження проаналізовано сутність понять «культура організації» і «організаційна культура», встановлено змістовне співвідношення між ними і зроблено їх розмежування. Посилено доказ, що культура організації являє собою матеріальний і духовний потенціал підприємства, а основою її розвитку є весь сукупний капітал підприємства. Особлива увага приділена організаційній культурі, як невід'ємному елементу культури організації, що відбиває духовно світоглядний стан, майстерність і мистецтво управління персоналом. Стверджується, що організаційна культура не лише унікальне управлінське, соціально-психологічне явище, а й дієвий інструмент для впровадження тактичних і стратегічних рішень, який здатний забезпечити конкурентостійкість та конкурентоздатність підприємства.
\end{abstract}

Ключові слова: організаційна культура, культура, культура організації, людський капітал, менеджмент, управління персоналом.

В статье освещается одна из проблем культуры предприятия - ее социальная подсистема, организационная культура. На основе теоретического исследования проанализированы сущность понятий «культура организации» и «организационная культура», установлено содержательное соотношение между ними и сделано их разграничения. Усиленно доказательство, что культура организации представляет собой материальный и духовный потенциал предприятия, а основой ее развития является весь совокупный капитал предприятия. Особое внимание уделено организационной культуре, как неотъемлемому элементу культуры организации, отражает духовно мировоззренческое состояние, мастерство и управление персоналом. Утверждается, что организационная культура не только уникальное управленческое, социально-психологическое явление, но и действенный инструмент для внедрения тактических и стратегических решений, которые способны обеспечить конкурентоустойчивость и конкурентоспособность предприятия.

Ключевые слова: организационная культура, культура, культура организации, человеческий капитал, менеджмент, управление персоналом.

On the basis of the conducted theoretical research, the article analyses the essence of the concepts "culture of organization" and "organizational culture", establishes the content relationship between them, and makes their differentiation. It is noted that in modern conditions of economic transformation, organizational culture is considered by scientists as one of the effective organizational, managerial, and social mechanisms, which is able to ensure the competitiveness of the enterprise, development of its economic potential and stability under destabilizing factors. It is proved that so far in the domestic and even in the foreign business and scientific environment there is no single interpretation and contradiction in views on the essence of organizational culture and the implementation of the substitution of this category by the term "culture of organization" with the same meaning. In the context of research methodology, the article analyses the works of both domestic and foreign authors, in which the categories of "culture of organization" and "organizational culture" are considered synonymous and given a scientific assessment. It is emphasized that such an approach to scientific categories, substituting some concepts for others, or vice versa, reducing them to identical ones does not allow to correctly assess the events taking place in the team and often leads to abuses in economics, social and scientific spheres. Some examples of differentiation of the terms "culture of organization" and "organizational culture", endowing them with consistent formulations, by scientists are presented and clarified. However, as stated in the article, such attempts are associated with both subjective and objective 
difficulties and causes. It has been suggested that such reasons may be the personal authority of scientists who consider these categories as synonyms, the limited scientific and theoretical basis, the changing system of values of society, etc. Studying the problem of the relationship between the two categories of the internal cultural environment of the enterprise and relying on scientists who try to identify the objective nature of the categories under study, the author comes to the following conclusions. The culture of the organization is the material and spiritual potential of the enterprise, and the total capital of the enterprise is the basis of its development. Organizational culture is an integral element of the culture of the organization, reflecting the spiritual worldview, skills and art of personnel management. The basis of organizational culture is the human capital and its intellectual reserve.

Keywords: organizational culture, culture, human capital, management, personnel management.

Постановка проблеми. В умовах переходу до ринкових методів господарювання, економічна стійкість підприємств і їх конкурентоздатність суттєво залежить від особливостей економічного середовища в країні, якості державного управління та якості менеджменту. В науковій літературі менеджмент тлумачиться як сукупність принципів, методів, фрорм, засобів і інструментів управління виробництвом 3 метою підвищення його ефективності. Менеджмент XXI століття на відміну від ідеологізованої адміністративної системи характеризується прийняттям управлінських рішень на основі використання сучасних механізмів і інструментів.

3 усього різноманіття таких інструментів і чинників, які існували в теорії менеджменту в минулому і існують в умовах сьогодення, виділяється організаційна культура.

Аналіз останніх досліджень і публікацій. Організаційна культура в умовах сьогодення набула статусу вагомої складової системи управління. Невипадково, вивченню проблем фрормування організаційної культури і її сутності присвятили свої дослідження багато іноземних (К. Камерон, У. Оучі, С. Робінс, Е. Шейн, Г. Ховтеде, О. Віханський) і вітчизняних фрахівців (Г. Дмитренко, О. Синицька, О. Грішнова, О. Харчишина та ін.). В їх роботах розкриваються основні напрями формування і розвитку організаційної культури, визначені методи і шляхи ії удосконалення. Водночас неможливо не помітити суперечливість у поглядах на проблему змісту організаційної культури, яка притаманна теорії менеджменту. Деякі, в тому числі відомі західноєвропейські, американські і навіть вітчизняні науковці здійснюють підміну одних понять іншими, вкладаючи в них один і той самий зміст. У контексті такого міркування знаходяться поняття «культура організації» $\mathrm{i}$ «організаційна культура» $\mathrm{i}$ змістовне співвідношення між ними. На наше переконання, щодо розмежування цих понять в теорії менеджменту вкрай обмежена інфрормація і методологічна бідність їх економічного аналізу.
Виділення невирішених раніше частин загальної проблеми. При наявному різноманітті досліджень в зарубіжному, вітчизняному діловому та науковому середовищ, дотепер відсутня суперечливість, єдине тлумачення у поглядах на сутність організаційної культури і здійснення підміни цієї категорії терміном «культура організації» вкладаючи в них один і той же зміст.

Формулювання цілей статті (постановка завдання). Економічна доля багатьох підприємств, яка спіткала їх в умовах транзитивної економіки в Україні, - тільки один із аргументів конче потрібної необхідності розібратися у змісті понять «культура організації» і «організаційна культура», зробити уточнене їх визначення і показати суттєві відмінності між ними.

Виклад основного матеріалу дослідження. Згідно 3 фрілософрським енциклопедичним словником термін «культура» (від лат. cultura - обробіток, розвиток, виховання, освіта, розвиток, шанування) - це сукупність способів і прийомів організації, реалізації та поступу людської життєдіяльності, способів людського буття; сукупність матеріальних і духовних надбань на певному історичному рівні розвитку суспільства і людини, які втілені в результатах продуктивної діяльності [1, с. 313]. За своєю сутністю і змістом вона $є$ універсальним терміном, який може бути застосований до будь-якого суб'єкта економічних та інших відносин, у тому числі підприємства. Останнє $є$ не просто виробничою структурою чи структурою для надання послуг, підприємство є соціально-культурним середовищем, в якому людина реалізує свої моральні, фрізичні і розумові здібності, передає свої знання і досвід наступним поколінням.

Проведений аналіз наукової літератури показав, що науковці які характеризують культуру підприємства у більшості випадків використовують одну з двох категорій: «культура організації» або «організаційна культура», при чому ототожнення цих понять в сучасній літературі набуває дедалі широкого використання. Наприклад автори відомої наукової роботи «Культура організації: проблеми 
срормування і управління» [2, с. 9] прямо зауважують: «В рамках даного підручника не робиться відмінностей між термінами «організаційна культура» і «культура організації»». Н.В. Наконечна також досліджуючи поняття «корпоративна культура», «організаційна культура», «культура організації» вважає, що не буде помилкою ототожнювати поняття організаційна культура і культура організації. [3, с. 8-9]. Більш категорично до проблеми культури відноситься Н.А. Шестиловська. На її думку, відмінності між організаційною культурою і культурою організації штучні і неправомірні. Культура організації як соціально-психологічний феномен ідентичний організаційній культурі [4, с. 74-75]. Таке категоричне твердження не зовсім коректне по відношенню до наукових термінів. 3 іншої сторони, проблема не в тім справедлива чи не справедлива позиція автора, а в тім, що на практиці підміна одних понять іншими, або навпаки зведення їх до ідентичних приводить до зловживань в економіці, соціальній та іншій сорерах.

На жаль, названі нами категорії використовуються як синоніми навіть відомими науковцями. Для конкретизації звернемо увагу на працю канадських науковців «Організаційна поведінка» [5], в якій автори, характеризуючи організаційні процеси, акцентують увагу на необхідності дослідження організаційної культури. Проте вже в розділі 17 автори цієї ж праці оцінюючи психологічні, соціальні, культурні, національні та інші чинники, що впливають на ефрективність роботи організації, дають визначення не організаційній культурі, а культурі організації. «Культура організації - комплексна картина надій, сподівань ідей, критеріїв вартостей (ціннісних орієнтацій), позицій та поведінки, прийнятих поміж членами певної організації». Якщо детальніше, - продовжують автори роботи, культура організації - це:

- звична поведінка, тобто ритуали організації, церемонії, а також мова, якою зазвичай користуються;

- норми, прийняті групами працівників у межах організації, скажімо, «чесна робота за чесну платню»;

- ціннісні орієнтації, які домінують в організації, наприклад «якість продукції» чи лідерство в ціноутворенні;

- фрілософрія, яка зумовлює політику організації стосовно ії працівників і клієнтів;

- правила гри, яких треба дотримуватися в організації, тобто «всі ходи і виходи», що їх треба вивчати новачкам, аби їх тут сприймали за своїх;
- атмоссрера, тобто відчуття, які викликані дизайном офрісу, манерою спілкування членів організації з клієнтами.

Жодна з цих компонент, взята окремо, не $€$ ознакою культури організації, однак у сукупності вони відображають концепцію культури організації і $€$ ії сутністю. Об'єктивно слід зазначити, що більшість із цих ознак культури лежить в основі терміна «організаційна культура», який використовується іноземними і вітчизняними науковцями.

Не ставлячи за мету перелік всіх наукових праць, що використовують терміни «культура організації» і «організаційна культура» як синоніми, скажемо відверто - спроби розмежувати ці поняття і наділити їх строгими і несуперечливими фрормулюваннями серед науковців існують, хоча вони і пов'язані 3 великими труднощами (особистий авторитет науковців, мінлива система цінностей суспільства, обмеженість науково-теоретичної бази тощо). Одні 3 них називають організаційну культуру «частиною культури, яка властива організації як певній групі людей, діяльність яких свідомо координується 3 метою досягнення певних цілей» [6], інші прямо констатують, що «культура організації» більш широке поняття ніж «організаційна культура». Під культурою організації А.М. Смолкін розуміє «сукупність загальних цінностей і норм поведінки, визнаних працівниками підприємства» [7, с. 67], а організаційну культуру визначає як «сукупність цінностей і норм організаційної поведінки, прийнятих на даному підприємстві» [7, с. 69]. Наведені, та інші підходи до визначення понять «організаційна культура» і «культура організації» та встановлення відмінностей між ними має теж явні прогалини, оскільки характеризуються неповнотою або неясністю, що не дозволяє виявити об'єктивну сутність цих категорій.

Усвідомлення необхідності приділяти підвищену увагу інструментам менеджменту, близько до розмежування понять «культура організації» і «організаційна культура» підійшла В.Г. Воронкова. На ії думку, поняття «організаційна культура» відображає ступінь організаційного упорядкування процесу виробництва і процесу менеджменту організації і $є$ тільки одним із елементів культури організації» [8, с. 140]. Слід зазначити, що цей підхід більш прогресивний за попередні. По-перше, в цьому визначенні основний методологічний підхід до теорії культури організації дотриманий. Так, справедливо відзначено, що організаційна культура $є$ елементом 
розвитку культури організації. По-друге, таке розуміння двох категорій дало підставу науковцю підтвердити точку зору Співака В.А. про те, що «культура організації - це сукупність матеріальних і духовних цінностей..., що відображають її неповторність та індивідуальність, проявляються в поведінці і взаємодії співробітників, їх сприйнятті себе в компанії і навколишнього середовища» [9, с. 27].

Матеріальні елементи культури організації (автор їх називає матеріалізованою культурою) відображають культуру виробництва, тобто ті елементи, які наймані працівники і суспільство можуть спостерігати, відчувати і сприймати. До них відносяться видимі (зовнішні) фрактори які Е. Шейн називає фракторами «поверхового рівня». Основні і допоміжні споруди, їх зовнішній вигляд, архітектура, розмір організації, фрірмовий і товарний знаки, технологія - це якраз ті матеріальні елементи які визначають сутність і зміст складових субкультур і мотиваційний вплив на трудовий колектив підприємства.

Проте діяльність підприємства не може здійснюватися лише на основі матеріалізованої культури. Підприємство - це не лише будинки, споруди, засоби виробництва і т.д. Це насамперед складний організм, орункціонування якого забезпечують люди, які мають свій менталітет, світогляд, соціальні, психофрізіологічні, естетичні, ціннісні судження в усвідомленні ними почуття причетності і відданості загальній справі. Наявність і визнання перелічених компонентів членами організації, їх передача від одного покоління до іншого характеризує особливості, які відрізняють одну організацію і її промислово-виробничий персонал від іншої. Автор їх відносить до духовно-світоглядних елементів культури організації, які визначають зміст культури працівників і їх міжособистісні відносини. Вони безпосередньо визначають поведінку найманих працівників у процесі їх індивідуальної і колективної діяльності в реалізації відповідних ступенів використання і розвитку матеріальних елементів культури організації.
Вони $є$ інтегруючим чинником, який характеризує взаємовідносини людей в процесі фрормування, розвитку і відповідних змін в діяльності організації і являють собою складову частину організаційної культури підприємства. Друга складова частина організаційної культури - це культура організації праці і виробництва. Вона представлена в нормах, стандартах і правилах внутрішнього порядку які встановлені власником (керівником) і закріплені в нормативно правових актах за допомогою яких забезпечуються внутрісистемні зв'язки, стійкість і ефективність діяльності підприємства.

Отже, «культура організації» - це сукупність і відповідний стан матеріалізованої і організаційної (нематеріалізованої) культури (рис. 1).

Матеріалізована культура представлена предметами середовища, які оточують і сприймаються за допомогою відчуттів людини. Ії̈ рівень і особливості фрункціонування залежать від розвитку матеріалізованих знань персоналу і удосконалення виробничих відносин в суспільстві.

Організаційна культура як соціальна підсистема культури організації - багатоаспектне творіння людей, яке відображає ступінь розвитку духовно світоглядних елементів і психологічного стану персоналу. Це соціально-духовне поле підприємства, у рамках якого взаємодія робітників здійснюється на основі загальних ідей, уявлень і цінностей, що визначають особливості їх трудової діяльності і дозволяють організації просуватися до успіху [6, с. 60].

Висновки. Дослідивши теоретичні і методологічні підходи провідних науковців щодо понять «культура організації» і «організаційна культура підприємства автор доходить таких висновків.

Культура організації як економічна категорія являє собою матеріальний і духовний потенціал підприємства, а основою її розвитку є весь сукупний капітал підприємства.

Організаційна культура - невід'ємний елемент культури організації, що відбиває

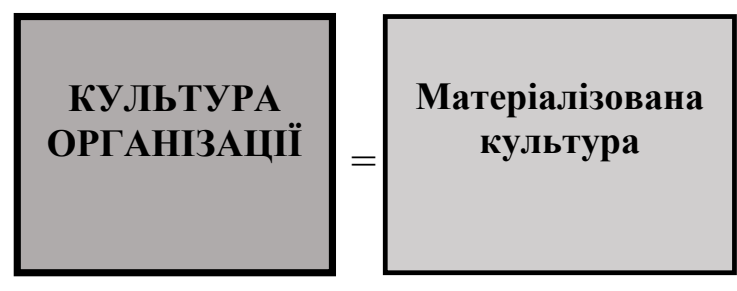

\begin{tabular}{|c|c|}
\hline O $\mathbf{p}$ г а н і з а ц і й н а & \multicolumn{1}{|c|}{$\mathbf{y}$ л ь т у р a } \\
\hline Культура & Культура \\
працівників i & організації \\
міжособистісних & праці і \\
відносин & виробництва \\
\hline
\end{tabular}

Рис. 1. Складові культури організації

Джерело: складено автором 
духовно світоглядний стан, майстерність і мистецтво управління персоналу. Основа організаційної культури - людський капітал і його інтелектуальний резерв.

Головною метою культури організації $\epsilon$ підвищення рівня іміджу підприємства і кон- курентних переваг шляхом кількісно якісного задоволення потреб споживача. Головною метою організаційної культури $є$ створення високоорганізованої поведінкової діяльності персоналу і здорового морально психологічного клімату в колективі.

\section{СПИСОК ВИКОРИСТАНИХ ДЖЕРЕЛ:}

1. Філософський енциклопедичний словник. Шинкарук В.І. (гол.ред.) та ін.; Ін-т фрілососрії ім. Г.С. Сковороди НАН України. Київ : Абрис, 2002.

2. Асаул А.Н., Асаул М.А., Ерофеев П.Ю., Ерофреев М.П. Культура организации: проблемы фрормирования и управления. СПб. : Гуманистика, 2006.

3. Наконечна Н.В. Психологічні умови розвитку корпоративної культури вищого навчального закладу приватної форми власності : автореф. дис. канд. псих. наук. Київ, 2016. URL: https://library.krok.edu.ua/media/ library/category/disertatsiji-avtoreferati-vidguki/nakonechna\%20_2016-aref.pdf

4. Шетиловская Н.А. Культура организации как социально-психологический френомен (с. 72-75). URL: https://elib.bsu.by/bitstream/123456789/39605/1/shestilovskja.pdf

5. Гелрігел Д., Слокум-молодший Дж.В., Вудмен Р.В., Бренінг Н.С. Організаційна поведінка / пер. $з$ англ. І. Тарасюк, М. Зарицька, Н. Гайдукевич. Київ : Вид-во Соломії Павличко «Основи», 2001.

6. Соломандина Т.О. Организационная культура компании. 2-е изд. Москва : ИНФРА-М, 2007.

7. Смолкин А.М. Менеджмент: основы организации. Москва : ИНФРА-М, 2012.

8. Воронкова В.Г., Беліченко А.Г., Попов О.М., Рєзанова Н.О. Управління людськими ресурсами: фрілософрські засади : навчальний посібник. Київ : ВД «Професіонал», 2006.

9. Спивак В.А. Корпоративная культура. СПб. : Питер, 2001.

\section{REFERENCES:}

1. Filosofskyi entsyklopedychnyi slovnyk [Philosophical encyclopedic dictionary] (2002) / Shynkaruk, V.I. (Ed.) In-t filosofii im. Skovorody, H.S. NAN Ukrainy. Kyiv: Abrys. (in Ukrainian)

2. Asaul, A.N., Asaul, M.A., Erofeev, P.Yu., Erofeev, M.P. (2006). Kultura organizacii: problemy formirovaniya $i$ upravleniya [Organization culture: problems of formation and management]. SPb.: Gumanistika. (in Russian)

3. Nakonechna, N.V. (2016) Psykholohichni umovy rozvytku korporatyvnoi kultury vyshchoho navchalnoho zakladu pryvatnoi formy vlasnosti [ Psychological conditions of the development of private educational institution corporate culture] Extended abstract of Candidate's thesis. Kyiv. University. URL: https://library.krok.edu.ua/media/library/ category/disertatsiji-avtoreferati-vidguki/nakonechna\%20_2016-aref.pdf (in Ukrainian)

4. Shetilovskaya, N.A. Kultura organizacii kak socialno-psihologicheskij fenomen [Organization culture as a socio-psychological phenomenon]. URL: https://elib.bsu.by/bitstream/123456789/39605/1/shestilovskja.pdf (in Russian)

5. Gelrigel, D., Slokum-molodshij, Dzh. V., Vudmen, R.V., Brening, N.S. (2001). Organizacijna povedinka [Organizational behavior] / per. z angl. I. Tarasyuk, M. Zaricka, N. Gajdukevich. Kyiv: Vid-vo Solomiyi Pavlichko «Osnovi». (in Ukrainian)

6. Solomandina, T.O. (2007) Organizacionnaya kultura kompanii [Organizational culture of the company]. 2nd ed. Moscow: INFRA-M. (in Russian)

7. Smolkin, A.M. (2012) Menedzhment: osnovy organizacii [Management: organization fundamentals]. Moscow: INFRA-M. (in Russian)

8. Voronkova, V.G., Belichenko, A.G., Popov, O.M., Ryezanova, N.O. (2006). Upravlinnya lyudskimi resursami: filosofski zasadi: navchalnij posibnik [Human resource management: philosophical principles]. Kyiv: VD «Profesional». (in Ukrainian)

9. Spivak, V.A. (2001) Korporativnaya kultura [Corporate culture]. SPb.: Piter. (in Russian) 